\title{
Knowledge and Opinions of Nursing Professionals about Pressure Ulcers Prevention
}

\begin{abstract}
Gabriela Cristina Alves Rodrigues ${ }^{1}$, Josilene de Melo Buriti Vasconcelos ${ }^{2}$, Fabrícia Maria de Araújo Bustorff Melo $^{3}$, Louise Passos Vigolvino ${ }^{4}$, Alana Tamar Oliveira de Sousa ${ }^{5}$, Iolanda Beserra da Costa Santos ${ }^{6}$, Analine de Souza Bandeira Correia ${ }^{1}$, Silvania Katiussa de Assis Gomes $^{3}$, Jacira dos Santos Oliveira² ${ }^{2}$ Cleane Rosa Ribeiro da Silva1, Ellen Martins Norat ${ }^{3}$
\end{abstract}

\section{Abstract}

Introduction: The pressure ulcer is a persistent public health problem, with burden to patients, family and health institutions. Health professionals should have appropriate knowledge to ensure the effectiveness on preventing of these injuries and treat them properly when they happen.

Objectives: Describing the knowledge of nursing professionals about prevention of pressure ulcers and analyzing their opinion on the same.

Methodology: It is characterized as an exploratory, descriptive and quantitative study conducted from January to June 2015, in a University Hospital; approved by the Ethics Committee of the institution. For data collection it was used the Pieper knowledge test and questions about opinions of professionals referring to the thematic.

Results: The study subjects were 32 nurses and 37 assistants/nursing technicians. The results showed approximate averages of correct answers in the general context of the knowledge test among nurses (75.60\%) and assistants/nursing technicians (76.29\%). It was found out that those professionals recognize the importance of preventing the injury, assure to be performed in the units where they work, but mention difficulties.

Conclusion: There were identified knowledge gaps about the pressure ulcer and its prevention, in both professional categories, which should be considered when planning strategies for staff training.
1 Nurse. Graduated at the Federal University of Paraíba, João Pessoa, Brazil.

2 Doctor in Sciences. Lecturer of Nursing Graduation at the Federal University of Paraíba, João Pessoa, Paraíba, Brazil.

3 Nurse of the University Hospital Lauro Wanderley, Federal University of Paraíba, João Pessoa, Paraíba, Brazil.

4 Nurse. Graduated at the Federal University of Campina Grande, Paraíba, Brazil.

5 Doctor in Nursing. Lecturer of Nursing Graduation at the Federal University of Campina Grande, Campus I, Cuité, Paraíba, Brazil.

6 Doctor in Health Sciences. Lecturer of Nursing Graduation at the Federal University of Paraíba, João Pessoa, Paraíba, Brazil.

\section{Contact information:}

Josilene de Melo Buriti Vasconcelos.

”josilenedemelo@gmail.com

Keywords

Pressure Ulcers; Patients'

Safety; Prevention; Nursing. 


\section{Introduction}

The pressure ulcer (UPP) is a serious public health problem that persists over the years, to the detriment of scientific and technological advances in healthcare. Through great burden to the patient, to the health system itself and still, to the difficult treatment of this type of injury, the UPP has been gaining ground in studies, especially those carried out by nursing professionals, as these are still the ones most involved in the development and implementation of preventive strategies, and in most cases, of treatment.

The UPP are defined as lesions located on the skin and/or tissue or underlying structure, generally over a bony prominence, resulting in isolation pressure, or of pressure combined with strain forces, and those forces are also associated with other factors still not clarified fully [1].

The International Classification of UPP [1] comprises: Category/Level I, characterized by intact skin with non-bleachable redness, in an area usually located over a bony prominence, which can be shown painful, firm or soft, warmer or colder, compared to the adjacent fabric; Category/Level II, which present partial loss of the skin; they are superficial (thin), with bright pink red layer, dry, without devitalized tissue or ecchymosis, or still are presented as closed or open phlyctena, filled with serous fluid; Category/Level III; they are characterized by subcutaneous fat exposure being not visible the bone, tendon or muscle, it may present some devitalized tissue that does not hide the depth of damaged tissues; and Category/Level IV, in which there is total loss of tissues with exposed bone, tendon or muscles; it may present devitalized tissue (necrosis liquefaction or coagulation), they are often cavities and fistulous. The guide also highlighted Ulcers with Unknown Classification (unrated), which are presented dark by the fibrin (yellow, beige, gray, green or brown) and/or necrosis (beige, brown or black) in its layer, which prevents determining its depth and category/le- vel; and those with Suspected Deep Tissue Injury, characterized as purple or brown area located on intact skin or phlyctena filled with blood due to damage on the underlying soft tissue caused by pressure and / or strain [1]. Risk factors for developing UPP are divided into two classes: intrinsic and extrinsic factors. Intrinsic are related to the individual physical characteristics of each one, such as: advanced age, malnutrition, tissue perfusion, the use of some medications and changes in the cardiovascular system. The extrinsic ones are related to the mechanisms of injury, such as strain forces, pressure and friction [2]. Depending on the risk factors to which he is exposed, the patient may present greater or lesser vulnerability to the development of UPP.

For the assessment of risk for UPP the international guidelines recommend the use of scales and highlight the Braden and Norton ones as those that have been most studied in the adult population, which are considered valid for the prediction of UPP risk in a variety of health institutions, beyond demonstrating reliability among the examiners, when applied by nurses or nursing technicians [3]. Of these scales, the most used in the world is the Braden Scale, which was translated to various languages and in Brazil has been validated to Portuguese [4].

However, authors recommend that the determination of the risk for the development of UPP, through a specific scale, should be associated to clinical trial to assess other risk factors that are not addressed in these instruments, and the result of this assessment should support planning assistance for prevention of UPP [5].

Currently, patient safety is one of the most critical issues for health. The growing need to reduce avoidable complications and prevent mistakes serves as a significant catalyst to encourage the use of evidence-based practices (EBP) at the bedside, which enables the reduction of avoidable complications [6], as it is the case of UPP. This type of 
injury, since 1995, is recognized by the American Nurses Association (ANA) as a quality indicator of nursing care [7]

In Brazil, there was created in 2013 the National Patient Safety Program, and along with it, multiple protocols, among which those of prevention of UPP. According to this protocol, most cases of UPP can be avoided by identifying risk patients and of the implementation of reliable prevention strategies for these patients [8]. However, to perform any program for the improvement of a care of quality for UPP prevention in the hospital, it becomes necessary to dimension the occurrence of the problem in all care settings, and to evaluate the knowledge of professionals about the appropriate ways of prevention and treatment.

The University Hospitals, since 2002, are part of the network of sentinel hospitals, which is formed in partnership with the Brazilian health services (hospitals, blood banks and diagnostic and therapeutic support services) responsible for the reporting of adverse events and technical complaints of health products; supplies, materials and medicines, sanitizers, kits for laboratory tests and medical and hospital equipment in use in Brazil [9]. Among the adverse events of health care, it is included the UPP. Thus, the professionals of these hospitals should be updated about the newest health care protocols, including pressure ulcer prevention.

In this context, it is expected that nursing professionals who deal directly with patients accommitted by UPP have proper knowledge about the problem: how this injury is developed, how its prevention and treatment are, and the main myths and truths related to the theme. Thus, it becomes important to evaluate the knowledge of these professionals, in order to detect possible gaps, and planning educational activities based on the best scientific evidences about the subject.

Given the above, this study aims to describing the knowledge of nursing professionals about pressure ulcer prevention, and analyzing their opinions about the prevention of the problem. It is hoped that with this study we can obtain support for conducting an educational intervention along with the nursing staff of the researched hospital.

\section{Methodology}

It considers an exploratory and descriptive study of a quantitative approach, performed in the units of the Surgical Clinic A (CCA), Internal Medicine wards $A$ and $B$ (CMA and CMB) and in the Clinic of Infectious and Contagious Parasitic Diseases (PID) of a teaching hospital located in the city of João Pessoa - PB. It composes a larger project in progress, which aims the difusion and implementation of UPP prevention protocol in inpatient units of the institution above mentioned. The referred project was approved by the Research Ethics Committee of the institution under CAAE: 399922314.7.0000.5183, Resolution 466/2012 [10], of the National Health Council (CONEP).

The population under this study involved nurses (61) and assistants/nursing technicians (105) working at those three clinics at the time of the study. To make the sample there was adopted the nonprobabilistic sample, obtained by accessibility [11], characterized as that one made up of individuals who met the inclusion criteria and were able work together with the researchers at the period of data collection. These criteria included: being a part of the effective staff of active servers in the mentioned hospital units, to be active at the period of data collection and being involved in direct patient care. The sample consisted of 69 participants, being 32 nurses (46.4\%) and 37 assistants/nursing technicians (53.6\%).

Data collection was carried out between January and June 2015 using an instrument consisting of questions relating to sociodemographic data, the Pieper knowledge test, validated and adapted in a previous study conducted in Brazil [12], and to the opinion of the professionals about prevention of 
UPP. The knowledge test was structured based on recommendations proposed by international guidelines and consists of 41 true or false statements with eight items on the evaluation and classification of the UPP (items 1, 6, 9, 20, 31, 32, 33 and 38) and 33 items about prevention of UPP [13], allowing to measure the level of knowledge of professionals about these two specific topics.

In each one of the test items, the participant must answer true $(\mathrm{V})$, False $(\mathrm{F})$ and Do not know (NS). In the analysis assigned punctuation for each hit, accounting for $V$ for true answers or $F$ for false. For wrong answers or those who answered as NS, there was assigned zero score. The total score of the knowledge test corresponded to the sum of all the correct answers. To sort the knowledge about the subject as appropriate, there was adopted the cutoff point recommended in the original study [13] in which establishes being necessary that the participants get it right $90 \%$ or more of the items in the test. In this study, total scores were categorized as follows: score ranges equal to or above $90 \%$, between 70 and $89.9 \%$ between 50 and $69.9 \%$ and below 50\%, in line with a similar study [14].

The instrument described was distributed to the participants who agreed to participate in the study and signed the free and informed consent. The same was answered individually in the own unit dependencies, and returned, without identification, ensuring the anonymity of the participant.

Data were entered into spreadsheet stored in $\mathrm{Mi}$ crosoft Office Exce/® 2010, containing the coding and a dictionary of all the variables. Afterwards, the data were imported into the Statistical Package for Social Sciences (SPSS) version 20.0 and analyzed through absolute and percentage frequencies for categorical variables, and average and standard deviation for numerical variables. To identify the possible association between the categorical variables we used the Chi-square test and when it did not meet the conditions for its application, there was used the Fisher's exact test or the test of likelihood ratio, considering their assumptions. In the comparison of means between two groups used the test $T$ Student. In all statistical tests, the significance level was $\alpha=0.05$.

\section{Results}

The study included 69 professionals, being 37 assistants/nursing technicians and 32 nurses. The sociodemographic data are presented in Table 1.

Table 1. Distribution of the professionals according to their socio-demographic characteristics. João Pessoa - PB, 2015.

\begin{tabular}{|c|c|c|c|c|c|c|}
\hline \multirow[t]{2}{*}{ Variables } & \multicolumn{2}{|c|}{$\begin{array}{l}\text { Assistants/ } \\
\text { Technicians } \\
\quad(n=37)\end{array}$} & \multicolumn{2}{|c|}{$\begin{array}{l}\text { Nurses } \\
(n=32)\end{array}$} & \multicolumn{2}{|c|}{$\begin{array}{c}\text { Total } \\
(n=69)\end{array}$} \\
\hline & $n$ & $\%$ & $n$ & $\%$ & $\mathrm{n}$ & $\%$ \\
\hline \multicolumn{7}{|l|}{ Gender } \\
\hline Female & 33 & 89.2 & 29 & 90.6 & 62 & 89.9 \\
\hline Male & 4 & 10.8 & 3 & 9.4 & 7 & 10.1 \\
\hline \multicolumn{7}{|l|}{ Age (in years) } \\
\hline$<30$ & 3 & 8.1 & 2 & 6.2 & 5 & 7.2 \\
\hline $30-40$ & 10 & 27.0 & 18 & 56.2 & 28 & 40.6 \\
\hline $40-50$ & 12 & 32.4 & 2 & 6.2 & 14 & 20.3 \\
\hline $50-60$ & 8 & 21.6 & 4 & 12.5 & 12 & 17.4 \\
\hline Did not refer & 4 & 10.9 & 6 & 18.9 & 10 & 14.5 \\
\hline \multicolumn{7}{|c|}{ Time of acting at in the unit (in years) } \\
\hline$<5$ & 17 & 45.9 & 20 & 62.5 & 37 & 53.6 \\
\hline $5-10$ & 2 & 5.4 & 2 & 6.2 & 4 & 5.8 \\
\hline $10-15$ & 7 & 18.9 & 7 & 22.0 & 14 & 20.3 \\
\hline $15-20$ & 2 & 5.4 & 1 & 3.1 & 3 & 4.3 \\
\hline $20-25$ & 5 & 13.5 & 2 & 6.2 & 7 & 10.1 \\
\hline$\geq 25$ & 2 & 5.4 & 0 & 0 & 2 & 2.9 \\
\hline Did not refer & 2 & 5.4 & 0 & 0 & 2 & 2.9 \\
\hline \multicolumn{7}{|c|}{ Participation on training about pressure ulcer } \\
\hline Yes & 13 & 35.1 & 15 & 46.9 & 28 & 40.6 \\
\hline No & 23 & 62.2 & 17 & 53.1 & 40 & 58.0 \\
\hline Did not refer & 1 & 2.7 & 0 & 0 & 1 & 1.4 \\
\hline
\end{tabular}


The data showed that the majority of participants were female $(89.9 \%)$ and in the age group between 30 to 40 years old (40.6\%). The average age of the assistants/nursing technicians was of 42.30 years old $(S D=8.52)$ and nurses of 38.15 years old $(S D=7.93)$.

Related to the training time. it was observed that most of the nurses had between 10 and 15 years of training (40.6\%) and among the assistants and technicians the percentage rates were evenly distributed in the ranges from 15 to 20 years old $(21.6 \%)$ and over 25 years old (21.7\%). The average time of the graduation was approached when comparing the nurses $(14.53 \%$. SD $=8.18 \%)$ and technicians/assistants (16.68\%. SD $=9.02 \%)$.

With regard to the operating time in the inpatient unit. most professionals (53.6\%) reported working for less than five years in the workplace. but the average time of performance of the sector was lower among nurses $(5.22 \%$. SD $=6.68 \%$ ) when compared to the technicians $(9.96 \%$. SD $=10.50 \%)$. Of the participants. $58.0 \%$ reported never having participated in training courses about the subject of UPP.

Concerning the results of the total scores of hits in the test of knowledge, by professional category, it was found that nurses had an average of $76.29 \%$ hits, and the assistants and technicians $75.60 \%$. There was no statistically significant in the association between the percentages of hits on the knowledge scale with the professional category.

Table 2 presents the results obtained by the professionals, through the knowledge test, the items evaluation and classification of the UPP.

It is observed that, in the knowledge of evaluation and classification of the UPP, the items 9 and

Table 2. Distribution of correct responses of the nursing team in the knowledge test, according to the items about evaluation and classification of pressure ulcer. João Pessoa - PB, 2015.

\begin{tabular}{|c|c|c|c|c|c|c|c|}
\hline \multirow[t]{2}{*}{ Variables } & \multicolumn{2}{|c|}{$\begin{array}{c}\text { Assistants/ } \\
\text { Technicians } \\
(n=37)\end{array}$} & \multicolumn{2}{|c|}{ Nurses $(n=32)$} & \multicolumn{2}{|c|}{ Total $(n=69)$} & \multirow[t]{2}{*}{$\mathbf{P}$} \\
\hline & $n$ & $\%$ & $n$ & $\%$ & $n$ & $\%$ & \\
\hline $\begin{array}{l}1 \text { The stage I of the pressure ulcer is defined by intact skin, } \\
\text { with hyperemia of an area located, which presents no } \\
\text { visible whitening or the color differs from the surrounding } \\
\text { area. (V) }\end{array}$ & 31 & 83.8 & 25 & 78.1 & 56 & 81.2 & $0.549 *$ \\
\hline $\begin{array}{l}6 \text { A pressure ulcers in stage III is a partial loss of the skin } \\
\text { involving the epidermis. (F) }\end{array}$ & 17 & 45.9 & 26 & 81.2 & 43 & 62.3 & $0.003^{*}$ \\
\hline $\begin{array}{l}9 \text { Pressure ulcer, in stage IV, exhibit loss of total skin with } \\
\text { intense destruction and tissue necrosis or damage to } \\
\text { muscles, bones and support structures. }(V)\end{array}$ & 36 & 97.3 & 30 & 93.8 & 66 & 95.7 & $0.445^{\star *}$ \\
\hline $\begin{array}{l}20 \text { Pressure ulcers in stage II feature a loss of skin in its total } \\
\text { thickness. (F) }\end{array}$ & 21 & 56.8 & 17 & 53.1 & 38 & 55.1 & $0.762^{*}$ \\
\hline 31 Pressure ulcers are sterile wounds. & 32 & 86.5 & 25 & 78.1 & 57 & 82.6 & $0.361^{*}$ \\
\hline $\begin{array}{l}32 \text { A region of skin with scar of pressure ulcers may be injured } \\
\text { more quickly than the healthy skin. }(\mathrm{V})\end{array}$ & 32 & 86.5 & 24 & 75.0 & 56 & 81.2 & $0.224^{*}$ \\
\hline $\begin{array}{l}33 \text { A bubble in the region of the calcaneus should not be of } \\
\text { concern. (F) }\end{array}$ & 35 & 94.6 & 31 & 96.9 & 66 & 95.7 & $0.555^{\star *}$ \\
\hline $\begin{array}{l}38 \text { Pressure ulcers of stage II can be extremely painful, due to } \\
\text { the exposure of nerve endings. }(\mathrm{V})\end{array}$ & 16 & 43.2 & 18 & 56.2 & 34 & 49.3 & $0.202^{*}$ \\
\hline
\end{tabular}


33 showed a higher percentage of hits (95.7\%). Items 1, 31 and 32 obtained percentage of $80 \%$ to $89.9 \%$, highlighting that in these items, the assistants/technicians got a percentage of hits more than the nurses. Items 6, 20 and 38 were below $70 \%$ of hits. In item 20 , once again, the percentage of hits of the assistants/technicians (56.8\%) was higher than that of the nurses (55.19\%). In contrast, in item 6 , the nurses had higher rate $(81.2 \%)$ than the assistants/technicians (45.9\%), being this diferrence statistically significant $(p=0.003)$. The lowest percentage of hits in the questionnaire was in item 38, which deals with the presence of pain in stage II UPP.

Table 3 presents the results derived from the responses to the questions directed to the knowledge about the prevention of UPP.

One can identify that among the 33 test items, referring to the prevention of UPP, there were 17 (51.5\%) items in which participants achieved more than $90 \%$ of hits, in $4(12.1 \%)$ items, 70 to $89.9 \%$ of hits, in 5 items (15.2\%) between 50 and 69.9\% of hits and in 7 items (21.2\%) the number of hits was below $50 \%$.

The results with lesser hit rate found in the study were: regarding the repositioning of patients sitting in chair (item 17; 29.0\%); regarding the use of cushions type waterwheels or air (item 14; 30.4\%); regarding the ideal elevation of the head of the bed in patients with UPP or at risk (item 16; 31.9\%); regarding patient positioning angle in relation to the bed in the lateral position (item15; 43.5\%); the frequency of skin inspection (item 3; 44.9\%); the use of water gloves or air under the calcaneus (item $13 ; 47.8 \%)$; and regarding the conduction massage in regions of hyperemia bony prominences (item 5; $49.3 \%)$.

Comparatively analyzing the knowledge of the two professional categories it is clear that nurses have higher level of knowledge to the detriment of assistants/technicians with significant statistics in the items 3 ( $p=0.025), 10$ (0.010) and 36 (0.021); and in the item $34(p=0.001)$ the technicians presented more knowledge than the nurses.

In the association between the percentages of correct answers on the knowledge scale according to professional category, there was not significant statistics, but there was a predominance of 70 to $89.9 \%$ of hits in both professional categories, with percentages higher between the assistants/technicians (78.4\%).

There was no statistically significant correlation between the percentage of correct answers in the test of the assistants/technicians and nurses with the correlation of the averages of age $(r=0.015$; $p=0.912)$, training time $(r=0.125 ; p=0.312)$ and length of service in the sector $(r=0.001 ; p=0.993)$.

Although there have been observed gaps in knowledge, it was observed that with respect to items dealing with the prevention of UPP, professionals have obtained a satisfactory percentage in most of the questionnaire, in contrast to the overall result of the test.

After analysis of professionals' skills, there was asked to them about their opinions on the prevention and preventive practices in their work sectors. It was observed that $100 \%$ of the study participants considered it important to the prevention of UPP, mainly because their realization contributes to decrease the length of stay and cost of treatment (52.35\%); prevents the increase of the health status of the patient $(38.5 \%)$ and reduces the incidence of UPP (20.0\%).

And the conduction of prevention in their workplace, $79.0 \%$ of the respondents reported that it is being held. The main difficulties encountered in implementing the prevention, according to the professionals were: the lack of a prevention protocol (72.7\%), insufficient human resources and the lack of continuity in carrying out preventive measures (both with 23.7\%). 
Table 3. Distribution of correct responses of the nursing team in the knowledge test, according to the items on the pressure ulcer prevention. João Pessoa - PB, 2015.

\begin{tabular}{|c|c|c|c|c|c|c|c|}
\hline \multirow[t]{2}{*}{ Variables } & \multicolumn{2}{|c|}{$\begin{array}{l}\text { Assistants/ Technicians } \\
\qquad(\mathrm{n}=37)\end{array}$} & \multicolumn{2}{|c|}{$\begin{array}{c}\text { Nurses } \\
(n=32)\end{array}$} & \multicolumn{2}{|c|}{$\begin{array}{l}\text { Total } \\
(n=69)\end{array}$} & \multirow[t]{2}{*}{$\mathbf{P}$} \\
\hline & $\mathrm{n}$ & $\%$ & $\mathrm{n}$ & $\%$ & $\mathrm{n}$ & $\%$ & \\
\hline $\begin{array}{l}2 \text { The risk factors for the development of pressure ulcers are: incontinence, inadequate nutrition and alteration of } \\
\text { consciousness level. (V) }\end{array}$ & 29 & 78.4 & 24 & 75.1 & 53 & 76.5 & $0.740 * * *$ \\
\hline 3 All patients at risk for pressure ulcer should have a systematic inspection of the skin at least once a week. (F) & 12 & 32.4 & 19 & 59.4 & 31 & 44.9 & $0.025^{* * *}$ \\
\hline 4 The use of warm water and soap can resect the skin and increase the risk for pressure ulcer. (V) & 17 & 45.9 & 19 & 59.4 & 36 & 52.2 & $0.265^{* * *}$ \\
\hline 7 All patients must be evaluated in the hospital admission as to the risk for the development of pressure ulcers. (V) & 33 & 89.2 & 22 & 100.0 & 65 & 94.2 & $0.076 * *$ \\
\hline $\begin{array}{l}8 \text { The creams, band-aids and curative dressings of ultra-thin Nuderm R help in skin protection against the effects } \\
\text { of the friction. }(V)\end{array}$ & 37 & 100.0 & 29 & 90.6 & 66 & 95.7 & $0.095^{\star *}$ \\
\hline 10 An adequate dietary intake of proteins and calories should be maintained during the disease/hospitalization. (V) & 30 & 81.1 & 32 & 100.0 & 62 & 89.9 & $0.010 * *$ \\
\hline 11 The patients that are limited to bed must be repositioned every 3 hours. (F) & 21 & 56.8 & 15 & 46.9 & 36 & 52.2 & $0.413 * *$ \\
\hline $\begin{array}{l}12 \text { A scale with timetables for decubitus change must be used for each patient with presence or at risk of pressure } \\
\text { ulcers. }(V)\end{array}$ & 34 & 91.9 & 29 & 90.6 & 63 & 91.3 & $0.602 * *$ \\
\hline 14 The cushions wheel type of water or air assist in pressure ulcer prevention. (F) & 11 & 29.7 & 10 & 31.2 & 21 & 30.4 & $0.891 * * *$ \\
\hline $\begin{array}{l}15 \text { In the lateral decubitus position, the patient with presence of pressure ulcer or at risk for the same must be at } \\
\text { an angle of } 30^{\circ} \text { in relation to the bed mattress. }(\mathrm{V})\end{array}$ & 17 & 45.9 & 13 & 40.6 & 30 & 43.5 & $0.657 * * *$ \\
\hline $\begin{array}{l}16 \text { In the patient with the presence of the pressure ulcer or at risk for same, the head of the bed should not be } \\
\text { raised at an angle greater than } 30^{\circ} \text {, if there is no medical contraindication. (V) }\end{array}$ & 13 & 35.1 & 9 & 28.1 & 22 & 31.9 & $0.533^{* * *}$ \\
\hline 17 The patient who does not move alone should be repositioned every 2 hours, when seated on the chair. (F) & 11 & 29.7 & 9 & 28.1 & 20 & 29.0 & $0.884^{* * *}$ \\
\hline $\begin{array}{l}18 \text { The patient with limited mobility and that can change the position of the body without aid, should be directed } \\
\text { to perform pressure relief, every } 15 \text { minutes, while seated on the chair. }(V)\end{array}$ & 24 & 64.9 & 18 & 56.2 & 42 & 60.9 & $0.456 * * *$ \\
\hline $\begin{array}{l}19 \text { The patient with limited mobility and that can stay in the chair, must have a cushion in seat for protection of } \\
\text { the region of bone protuberances. }(V)\end{array}$ & 35 & 94.6 & 30 & 93.8 & 65 & 94.2 & $0.636^{* *}$ \\
\hline 21 The skin of the patient with risk for pressure ulcer must remain clean and free of moisture. (V) & 36 & 97.3 & 29 & 90.6 & 65 & 94.2 & $0.254 * *$ \\
\hline
\end{tabular}




\begin{tabular}{|c|c|c|c|c|c|c|c|}
\hline \multirow{2}{*}{ Variables } & \multicolumn{2}{|c|}{$\begin{array}{l}\text { Assistants/ Technicians } \\
\qquad(\mathrm{n}=37)\end{array}$} & \multicolumn{2}{|c|}{$\begin{array}{l}\text { Nurses } \\
(n=32)\end{array}$} & \multicolumn{2}{|c|}{$\begin{array}{l}\text { Total } \\
(n=69)\end{array}$} & \multirow[t]{2}{*}{$\mathbf{P}$} \\
\hline & $n$ & $\%$ & $n$ & $\%$ & $n$ & $\%$ & \\
\hline $\begin{array}{l}22 \text { The measures to prevent new lesions need not be adopted continuously when the patient already has pressure } \\
\text { ulcer. (F) }\end{array}$ & 33 & 89.2 & 32 & 100.0 & 65 & 94.2 & $0.076 * *$ \\
\hline 23 The linens mobile or sheets should be used to transfer or move patients that do not move alone. (V) & 35 & 94.6 & 30 & 93.8 & 65 & 94.2 & $0.636 * * *$ \\
\hline $\begin{array}{l}24 \text { The mobilization and the transfer of patients that do not move alone should always be performed by two or } \\
\text { more persons. }(V)\end{array}$ & 35 & 94.6 & 30 & 93.8 & 65 & 94.2 & $0.636 * *$ \\
\hline $\begin{array}{l}25 \text { In the patient with chronic condition that does not move on its own, the rehabilitation should be initiated and } \\
\text { include guidelines on the prevention and treatment of pressure ulcers. }(\mathrm{V})\end{array}$ & 34 & 91.9 & 31 & 96.9 & 65 & 94.2 & $0.363 * *$ \\
\hline $\begin{array}{l}26 \text { Every patient who does not wandering should be submitted to the assessment of the risk for the development } \\
\text { of pressure ulcers. }(\mathrm{V})\end{array}$ & 35 & 94.6 & 31 & 96.9 & 66 & 95.7 & $0.555^{\star *}$ \\
\hline $\begin{array}{l}27 \text { The patients and family members should be advised as to the causes and risk factors for the development of } \\
\text { pressure ulcers. }(V)\end{array}$ & 35 & 94.6 & 32 & 100.0 & 67 & 97.1 & $0.284^{* *}$ \\
\hline 28 The regions of bone protuberances can be in direct contact with one another. (F) & 32 & 86.5 & 31 & 96.9 & 63 & 91.3 & $0.136 * *$ \\
\hline 30 The skin, when macerated by moisture damage it is easily. (V) & 34 & 91.9 & 32 & 100.0 & 66 & 95.7 & $0.148 * *$ \\
\hline 34 A good way to relieve the pressure in the calcaneus is to keep them high in bed. (V) & 31 & 83.8 & 15 & 46.9 & 46 & 66.7 & $0.001 * * *$ \\
\hline 35 All the care to prevent or treat pressure ulcers need not be registered. (F) & 34 & 91.9 & 29 & 90.6 & 63 & 91.3 & $0.591 * *$ \\
\hline 36 Strain is the force that occurs when the skin adheres to a surface and the body slides. (V) & 19 & 51.4 & 25 & 78.1 & 44 & 63.8 & $0.021 *$ \\
\hline 37 The friction can occur when moving the patient on the bed. (V) & 32 & 86.5 & 30 & 93.8 & 62 & 89.9 & $0.279 * *$ \\
\hline $\begin{array}{l}39 \text { In the patient with incontinence, the skin should be cleaned at the moment of the eliminations and in routine } \\
\text { intervals. }(V)\end{array}$ & 35 & 94.6 & 30 & 93.8 & 65 & 94.2 & $0.636 * *$ \\
\hline 40 The development of the educational programs in the institution may reduce the incidence of pressure ulcers. (V) & 35 & 94.6 & 31 & 96.9 & 66 & 95.7 & $0.555^{* *}$ \\
\hline $\begin{array}{l}41 \text { The hospitalized patients need to be evaluated as to the risk for pressure ulcer only once during their } \\
\text { hospitalization. (F) }\end{array}$ & 35 & 94.6 & 32 & 100.0 & 67 & 97.1 & $0.284^{\star *}$ \\
\hline
\end{tabular}




\section{Discussion}

The nursing team is directly linked to questions turned to patients' safety, given that they are responsible for most of the daily care to the same. By observing the patient systematically and frequently the nursing professional has the opportunity to identify potential risks for adverse care problems and intervene so that they do not settle. Thus, emerges the need to search for knowledge and skills, aiming the excellence of care, contributing to a faster recovery of the patient.

One of the most frequent problems in bedridden patients which can be prevented through simple and systematic care, of the responsibility of all professionals, but with special relationship with nursing care is the UPP. It is true that this injury brings serious consequences to the patient, what contributes to worsening his health; because, besides the distress increases the length of hospitalization and the risk of developing infections, it rises considerably [15-16]. The UPP also causes workload in health professionals, increases the use of material resources and hospitalization costs [17].

Currently, there are added to these aspects, the ethical and legal implications related to the occurrence of the UPP, actually considered as bodily injury, according to the Brazilian Penal Code, includes harm to body or health integrity of another [18].This assertion supports affirmatives of authors who attribute the emergence of UPP to deficiency in attention and care to vulnerable patients, so that professionals can be blamed for their occurrence [19].

Thus, there are justified any efforts turned to prevention of the problem, from the best scientific evidences about the subject, so that professionals act jointly and through clinical protocols to ensure the uniformity and effectiveness of preventive care. In this respect, there is a lack of UPP prevention protocols in units of work of professionals, a fact cited by them as difficulty for the effective use of recommendations for prevention. The literature has [20-
21] some protocols with comprehensive approaches to the patient's needs, but the professional can base to prepare a specific protocol for his service, so that favors the systematization of nursing care, optimize decision-making and reduce the incidence of the problem.

It is worth mentioning that for the use of recommendations proposed in protocols, it is of crucial importance to the staff training to ensure knowledge in the specific area. Studies show how important is the continuity of education as a major factor in changing the practice of nursing staff with a view to continuing education actions provide basis for the debate and improving service through innovative proposals, and offer professional the possibility of acquiring new knowledge and work as a multiplier of the same [22-23]. Moreover, it is necessary to assess the level of professional knowledge and the need for training courses.

The text presents as a result, considering the total of agreed items that nurses obtained $76.29 \%$ of correct answers in the questionnaire, while the auxiliary/ nursing technicians hit $75.60 \%$ of all statements, highlighting that both categories not reached the ideal value adjustments. For that knowledge was considered sufficient, professionals should have hit at least $90 \%$ of affirmative proposals [13]. It is worth noting that only 3 assistants/technicians and three nurses (4.3\%), hit $90 \%$ or more of the instrument, reaffirming the need for training and updating of the nursing team which was submitted to the test in question.

The pioneering research that used this instrument found that the average percentage of correct answers was $71.7 \%$, average achieved by 228 nurses from two North American hospitals. The study also showed that knowledge was higher in the group that had participated in some way of training or had access to an article on the subject in question [13].

A study conducted with 386 members of the nursing staff of a university tertiary referral hospital in Brazil, being from these 250 assistants/technicians 
and 136 nurses showed a greater hit in the nurse category, with average of $79.4 \%$ (SD $=8.3 \%$, and the assistants/ nursing technicians with $73.6 \%$ of hits [14].

Another study conducted in a Brazilian university hospital in the city of Montes Claros, in the state of Minas Gerais, with 85 nursing professionals, including nine (10.58\%) were nurses and 76 (89.42\%) nursing technicians, obtained as a result: the majority of nurses (78\%) hit between $70-90 \%$ of the test, while only $22 \%$ got more than $90 \%$, and none received less than $70 \%$ of hits. Most nursing technicians (88\%) had little knowledge about the ulcer prevention recommendations, and $5 \%$ of them hit less than $70 \%$ of the questions, $83 \%$ hit between 70 and $90 \%$ and only $12 \%$ had more than $90 \%$ hits [24].

Research implemented with 37 nursing workers: 5 nurses, 6 technicians and 26 nursing assistants, in a semi-intensive care unit of a university tertiary referral hospital in Curitiba, Paraná, showed that nurses got an average of 33.6 hits (81.95\%), nursing assistants 30.9 hits (75.33\%) and the technicians 28 hits (68.29\%) [25].

The study was performed in two nursing services, General Surgery (CG) and Digestive System Surgery (CAD) in the same hospital mentioned above. CG inpatient unit, 13 professionals were involved in the research: five nurses, four technicians and four assistants. In the sector of CAD 12 answered to the form: a nurse, six technicians and five nursing assistants. The individual results of the sectors show batting average of $78.24 \%$ hits in the CG sector and $69.51 \%$ in the CAD service. None of the units has reached a score considered satisfactory, which would be of 37 hits or more, since the average of the two units was of $73.88 \%$ hits [26].

As can be seen, the results of the original study [13] and national studies in university hospitals [2426] reveal gaps in knowledge of all nursing classes, in that it is the UPP theme. The technical and scientific knowledge about the subject should be sought by both professionals, as provided by health institutions that they are inserted [24-26].

It is noteworthy in the context of prevention of UPP the need and importance of evaluating the risk for development of this problem, through effective assessment tools, since they are not invasive and low cost to the institution, to facilitate the distinction of patients at risk for UPP and which are not. Thus one can identify the degree to which a person presents a factor of particular risk, thus directing the choices of actions needed [27]. In this study, the professionals of the two categories demonstrated by high rates of correct answers in the items on risk assessment for $\operatorname{UPP}$ (7, 26 and 41), which recognize the need to evaluate at the time of admission and subsequent daily revaluations this.

Diverse instruments for the evaluation of risk for pressure ulcers are cited in the literature as the Norton scales, Gosnell, Waterlow and Braden [28], being the most used the Braden Scale, validated in Brazil. Its use requires little skill professional although they sometimes require more time in the assistance to improve the quality and efficiency of the same. Therefore, the said scale is of utmost importance to the prognosis, since the identification of patients at risk allows the use of preventive measures, which can reduce by half the incidence of UPP [29-30].

Another important aspect of preventive care is the systematic assessment of the patient's skin, on which was found another gap in the study. The data showed that the percentage of correct answers of the assistants/nursing technicians (32.4\%) and nurses $(59.4 \%)$ was lower than expected. The evaluation of the skin and tissues is important to prevent, classify, diagnose and treat UPP [1].

The literature reports that the skin assessment in individuals at risk of developing UPP must be held at the following times: as soon as possible but within a maximum period of eight hours after admission (or first consultation in a community context); as part of all risk assessments; continuously, based on the clinical context and the individual degree of risk 
and before the individual is discharged. Continuous assessment of the skin is essential for early detection of pressure damage, especially over bony prominences [1].

It becomes necessary to conduct a general assessment of the patient with emphasis on skin areas overlying the bony prominences, including the sacrum, ischial tuberosity, the trochanters and heels, can be enjoyed every repositioning for a rapid assessment of the skin is carried out, remembering to increase the frequency of skin ratings in response to any deterioration in the general condition [1]. The Brazilian National Program for Patient's Safety, in the protocol that deals with the UPP, brings six essential stages of a UPP prevention strategy, and the daily skin inspection is among them [8].

It was possible to observe through the study results a significant deficiency known to practitioners as it is for the prevention of UPP for proper positioning and early repositioning of patients (items 11, $15,16,17)$, the use of materials for relief pressure (items 13 and 14), as the use of massage as an effective measure for the prevention (item 5) and the skin inspection frequency (item 3).

Repositioning aims to reduce the duration and magnitude of pressure over vulnerable areas of the body and contribute to the comfort, hygiene, dignity and the individual's functional capacity [1]. In individuals where it is not possible to perform the repositioning should be used other strategies for pressure relief as, for example, a mattress or a bed of high especifity [1]. Regarding the use of massage, there are contraindicated in bony prominences, especially when we started the development of UPP [2].

Considering the results of the study there are perceived important notes to be observed in the training of professionals in order to improve the quality of preventive practices in the institution. Undoubtedly, the success of prevention of UPP is directly linked to the knowledge and skills of health professionals about the subject, in particular the members of the nursing team who provide direct and per- manent care to patients [14]. However, one cannot minimize the institution's role in the provision of adequate resources for prevention and maintaining a permanent education policy for the whole team, enabling the circulation of scientific evidences to the practice field.

\section{Conclusion}

From the study results it was found that the average of correct answers obtained by the Pieper evaluation tool for nurses (average $=76.29 \%$, SD $=12.92 \%$ ) and nursing assistants/ technicians (average $=75.6 \%, S D=13.37 \%$ ) denote important knowledge gaps about the UPP and its prevention, indispensable for targeting preventive actions on working practices of professionals. These findings indicate the need for continuing education activities for preparation and updating of nursing professionals to work in this area at the same time when they can guide the actions to be performed.

It can be assured, before the results of the study, that all nursing professionals attach importance to the prevention of UPP and still refer that this is carried out in the workplace. But through the gaps in knowledge about the subject, it questions whether the practice of this prevention is actually being effective and is contributing to reducing the incidence of the problem. Thus, the present study instigates future studies which can be evaluated the practice directed to preventing the UPP and the impact of the implementation of the recommendations for prevention about the incidence of the problem.

The gap that arises in the present study is the reduced number of participating professionals. One of the reasons that may be related to this fact was the demand for work during the time of the survey, which led many professionals to refuse to answer the proposed instrument. 


\section{References}

1. National Pressure Ulcer Advisory Panel, European Pressure Ulcer Advisory Panel and Pan Pacific Pressure Injury Alliance. Prevention and Treatment of Pressure Ulcers: Quick Reference Guide. Emily Haesler (Ed.). Cambridge Media: Perth, Australia; 2014

2. Martins DA, Soares FFR. Conhecimento sobre prevenção e tratamento de úlceras de pressão entre trabalhadores de enfermagem em um hospital de minas gerais. Cogitare Enferm. [internet]. 2008; 13(1):83-7. Disponível em: http://ojs.c3sl.ufpr. br/ojs/index.php/cogitare/ article/view/11956.

3. Wound, Ostomy, and Continence Nurses Society (WOCN). Guideline for prevention and management of pressure ulcers. Mount Laurel (NJ): Wound, Ostomy, and Continence Nurses Society (WOCN); 2010 Jun 1. 96 p. (WOCN clinical practice guideline; n.2).

4. Paranhos WY, Santos VLCG. Avaliação de risco para úlceras de pressão por meio da escala de Braden, na língua portuguesa. Rev Esc Enferm USP. [Internet]. 1999; 33(1):191-206. Disponível em: http://www.ee.usp.br/reeusp/upload/pdf/799.pdf.

5. Vasconcelos JMB. Construção, utilização e avaliação dos efeitos de protocolo de prevenção de úlceras por pressão em Unidade de Terapia Intensiva. [Tese Doutorado]. Ribeirão Preto: Escola de Enfermagem de Ribeirão Preto/USP. [Internet]. 2014; 342f. Disponivel em: http://www.teses.usp.br/teses/ disponiveis/22/22132/tde-21052014-192211/

6. Institute for Patient- and Family-Centered Care. Advancing the Practice of Patient- and Family-Centered Care in Hospitals: How to Get Started. Bethesda, MD. [Internet]. 2011. Disponível em: http://www.ipfcc.org/pdf/getting started.pdf.

7. Nogueira PC, Caliri MHL, Santos CB. Fatores de risco e medidas preventivas para úlcera de pressão no lesado medular. Experiência da equipe de enfermagem do Hospital das Clinicas da FMRP-USP. Medicina, Ribeirão Preto. [Internet]. 2002; 35(1):14-23. Disponível em: http://www.revistas.usp.br/rmrp/ article/view/787/798

8. Brasil. Ministério da Saúde. Agência Nacional de Vigilância Sanitária. Fundação Oswaldo Cruz. Protocolo para prevenção de úlcera por pressão. [Internet]. 2013. Disponível em: http://www. hospitalsantalucinda.com.br/downloads/prot prevencao ulcera_por_pressao. pdf.

9. Brasil. Ministério da Saúde. Agência Nacional de Vigilância Sanitária. Rede sentinela. 2009. Disponível em: http://www. anvisa.gov.br/servicosaude/hsentinela/index.htm.

10. Brasil. Conselho Nacional de Saúde. Resolução $n^{\circ} 466$, de 12 de dezembro de 2012. Aprova normas regulamentadoras de pesquisas envolvendo seres humanos. Brasília: Diário Oficial da União, 2013

11. Richardson RJ. Pesquisa Social: métodos e técnicas. 3a ed. São Paulo: Atlas; 2009.

12. Fernandes LM, Caliri MHL, Haas VJ. Efeito de intervenções educativas no conhecimento dos profissionais de enfermagem sobre prevenção de úlceras por pressão. Acta Paul. Enferm. [Internet]. 2008; 21(2):305-11. Disponivel em: http://www. scielo.br/pdf/ape/ v21n2/pt a12v21n2.pdf
13. Pieper B, Mott M. Nurses' knowledge of pressure ulcer prevention, stating, and description. Adv Wound Care. 1995; 8(3):34-48.

14. Miyazaki MY, Caliri MHL, Santos CB. Conhecimento dos profissionais de enfermagem sobre prevenção da úlcera por pressão. Rev. Latino-Am. Enfermagem. [Internet]. 2010; 18(6):[10 telas]. Disponível em: http://www.scielo.br/pdf/rlae/ v18n6/pt 22. pdf.

15. Parra DL, Camargo-Figueira FA, Gómez RR. Eventos adversos derivados del cuidado de enfermería: flebitis, úlceras por presión y caídas. Enferm. glob. [Internet]. 2012; 11(4). Disponível em: http:// scielo.isciii.es/scielo.php?pid=S1695-61412012000400010\& script $=$ sci arttext.

16. Nogueira PC, Godoy S, Mendes IAC, Roza DL. Conhecimento dos cuidadores de indivíduos com lesão medular sobre prevenção de úlcera por pressão. Aquichan. [Internet]. 2015; 15(2):188-199. Disponível em: http://aquichan.unisabana.edu. co/index.php/aquichan/ article/view/3492.

17. Pott FS, Ribas JD, Silva OBM, Souza TS, Danski MTR, Meier MG. Algoritmo de prevenção e tratamento de úlcera por pressão. Cogitare enferm. [Internet]. 2013; 18(2):238-44. Disponível em: http://ojs.c3sl.ufpr.br/ojs/index.php/cogitare/ article/download/26085/206 85 .

18. Brasil. Casa Civil da Presidência da República. Decreto-Lei n. 2.848, de 7 de dezembro de 1940. Institui o Código Penal. Brasília, 1940.

19. Ramos DO, Oliveira OS, Santos IVA, Carvalho ESS, Passos SSS, Góis JA. Conhecimento de familiares acerca das úlceras por pressão e de seus direitos à reparação. Rev. baiana enferm. [Internet]. 2014; 28(1):23-30. Disponível em: http://www.portalseer .ufba. br/index.php/enfermagem/article/download/8545/8714.

20. Almeida RA, Bastos RAA, Almeida FCA, Pequeno GA, Vasconcelos JMB, Rodrigues FA. Avaliação da utilização de protocolos na prevenção de úlceras por pressão. Rev Ciência \& Saúde. [Internet]. 2012; 5(2):125-131. Disponível em: http:// revistaseletronicas.pucrs.br/ojs/index.php/faenfi/article/ view/10457.

21. Medeiros $A B F$, Lopes $C H A F$, Jorge MSB. Análise da prevenção e tratamento das úlceras por pressão propostos por enfermeiros. Rev Esc Enferm. USP. [Internet]. 2009; 43(1):223-8. Disponível em: http://www.scielo.br/scielo.php?script=sci artte xt\&pid=S0080-62342009000100029.

22. Silva LAA, Ferraz F, Lino MM, Backes VMS, Schmidt SMS. Educação permanente em saúde e no trabalho de enfermagem: perspectiva de uma práxis transformadora. Rev Gaúcha Enferm. [Internet]. 2010; 31(3):557-61. Disponivel em: http://www.scielo.br/scielo.php?script=sci artte xt\&pid=S1983-14472010000300021.

23. Morais Filho LA, Marinho CSR, Backes VMS, Martini JG. Continuing healthcare education: a strategy to connect teaching and services. Rev Rene. [Internet]. 2013; 14(5):105060. Disponível em: http://www.revistarene.ufc.br/revista/index. php/revista/article/ download/102/pdf 
24. Rocha LES, Ruas EFG, Santos JAD, Lima CA, Carneiro JA, Costa FM. Prevenção de úlceras por pressão: avaliação do conhecimento dos profissionais de enfermagem. Cogitare Enferm. [Internet]. 2015; 20(3):596-604. Disponível em: http://ojs.c3sl.ufpr.br/ojs/index.php/_ cogitare/article/ view/41750.

25. Mauricio AB, Lemos DS, Crosewski NI, Roehrs H. Conhecimentos dos profissionais de enfermagem relacionados às úlceras por pressão. Rev. enferm. UFSM. [Internet]. 2014; 4(4):751760. Disponível em: http://periodicos.ufsm.br/reufsm/article/ view/11707/pdf

26. Crosewski NI, Lemos DS, Mauricio AB, Roehrs $H$, Meier AJ. Conhecimento dos profissionais de enfermagem sobre úlceras por pressão em duas unidades cirúrgicas - parte 1. Cogitare Enferm. [Internet]. 2015; 20(1):74-80. Disponível em: http://ojs. c3sl.ufpr.br/ojs/ index.php/cogitare/article/view/35097.

27. Bryant RA, Nix DP. Developing and maintaining a pressure ulcer prevention program. Acute \& chronic wounds: current management concepts. 4a ed. St. Louis (Missouri): Elsevier Mosby; 2012. Chap. 8: p. 137-153.

28. Jorge SA, Dantas SRPE. Abordagem multiprofissional do tratamento de feridas. São Paulo: Atheneu; 2003. Cap. 9: p. 101-109.

29. Borghardt AT, Prado TN, Araújo TM, Rogenski NMB, Bringuente MEO. Evaluation of the pressure ulcers risk scales with critically ill patients: a prospective cohort study. Rev. Latino-Am Enfermagem. [Internet] 2015; 23(1). Disponível em: http://www. scielo.br/scielo.php?script=sci_arttext\&pid =S0104-11692015000100028.

30. Araújo TM, Araújo MFM, Caetano JA, Galvão MTG, Damasceno MMC. Diagnósticos de enfermagem para pacientes em risco de desenvolver úlcera por pressão. Rev Bras Enferm. [Internet]. 2011; 64(4):671-676. Disponível: http://www.scielo.br/pdf/ reben/ v64n4/a07v64n4.pdf.
Publish in International Archives of Medicine

International Archives of Medicine is an open access journal publishing articles encompassing all aspects of medical science and clinical practice. IAM is considered a megajournal with independent sections on all areas of medicine. IAM is a really international journal with authors and board members from all around the world. The journal is widely indexed and classified Q1 in category Medicine. 